\title{
SEARCHING FOR STANDARDS: DISCLOSURE IN THE MUNICIPAL SECURITIES MARKET ${ }^{\dagger}$
}

\author{
John E. Petersen,* Robert W. Doty,** \\ RONALD W. FORBES*** AND DONALD D. BOURQUE****
}

The year 1975 was a turbulent one for the usually placid municipal bond market. An unrelenting series of stresses was exerted, most of which were connected with the struggles of New York City and State to avoid defaulting upon their billions of dollars of outstanding debt. ${ }^{1}$ While the municipal bond market worried over the possibility of sucli a calamity, it was further agitated by a lost of other factors: a general weakness in institutional investor demand for tax-exempt securities, an erosion of the economic and fiscal circumstances in several cities and states, questions about the sanctity of the municipal debt contracts, a liberalizing of the federal bankruptcy provisions, a new regulatory scheme for nunicipal bond dealers, and the possibility of more intense judicial scrutiny of municipal bond transactions under the anti-fraud

$\uparrow$ This paper was prepared in connection with a project on Municipal Credit Information and Quality sponsored by the Municipal Finance Officers Association and funded by the National Science Foundation (NSF/RANN APR 75 - 17227).

* Director of the Center for Policy Research and Analysis, National Governors' Conference, Washington, D.C. B.A. 1962, Northwestern University; M.B.A. 1964, Wharton School of Finance, University of Pennsylvania; Ph.D. in Monetary Economics, 1968, University of Pennsylvania.

** Associate Professor of Law, Creighton University School of Law, Omaha, Nebraska. B.A. 1964, University of Houston; LL.B. 1967, Harvard Law School.

*** Associate Professor of Finance, School of Business, State University of New York at Albany. A.B. 1961, Dartnouth College; Ph.D. 1968, State University of Buffalo.

**** Professor of Accounting and Associate Deau, School of Business, State University of New York at Albauy. A.B. 1960, University of Washington; Ph.D. 1964, University of Washington.

THE FOLLOWING CITATION WILL BE USED IN THIS ARTICLE:

Municipal Fin. Officers Ass'n, Disclosure Guidelines for Offering of SecuRITIES BY STate AND LOCAL GovernMENTS (Exposure Draft 1975) [hereinafter cited as Guidelines]. (The Guidelines are available from Municipal Finance Officers Association, 1313 East 60th Street, Chicago, Illinois 60637.)

1. The New York crises and their consequences have been richly documented elsewhere. See, e.g., Cong. Budget Office, New York City's Fiscal Problem: Its Origins, Potential Repercussions, and Some Alternative Policy Responses (Background Paper No. 1, Oct. 10, 1975), reprinted in full, Hearings on S. 1833, S. 1862, S. 2514 and S. 2523 Before the Senate Comm. on Banking, Housing and Urban Affairs, 94th Cong., 1st Sess. (1975); JoInt ECON. CoMm., 94tH CONG., 1sT SEss., NEw York City's Financial Crisis, An Evaluation of its Economic Impact and of ProPOSED POLICY Solutrons (Comm. Print 1975). 
provisions of the federal securities laws. ${ }^{2}$ Through it all, the municipal bond market not only managed to survive, but witnessed a recordsetting level of securities sales: $\$ 60$ billion in new issue notes and bonds were sold in $1975 .^{3}$

Although 1976 brought a revival of both spirits and prices to match the high sales volumes in the inunicipal securities inarket, ${ }^{4}$ niany of the questions which surfaced in 1975 remain unresolved. Perhaps the most significant of these lingering issues is the extent to which the federal securities laws should be inade applicable to transactions involving inunicipal securities. At this point, there is no direct regulation of municipal issuers by the federal government. The general anti-fraud provisions of the federal securities laws are applicable to municipal securities; however, the responsibilities of a municipal issuer to disclose information under these provisions are still untested.

In assessing the propriety of direct federal regulation and determiming the duties of the mumicipal issuer under the anti-fraud provisions, a knowledge of the current disclosure practices of these issuers is essential. After discussing in more detail how such information could be used, this Article will report on two recent surveys of the level of voluntary disclosure of information accompanying the distribution of municipal bonds. The results of these surveys indicate that there is a trend toward greater disclosure, largely in conformity with the Guidelines promulgated by the Municipal Finance Officers Association, a professional group representing the interests of municipal issuers. A discussion of the significance of this development in terms of the potential extension and present applicability of the federal securities laws will follow the presentation of the survey results.

\section{Federal Regulation of Municipal Issuers}

Governmental and investor wariness over the stability of the market for municipal bonds has been manifested in two principal ways:

2. For a discussion of conditions in the municipal bond market see J. PETERSEN, Changing Conditions in the Market for State and Local Government DebT (1976) (prepared for Joint Economic Committee, 94th Congress, 2d Session).

3. In 1975 , new long-term bond sales totaled $\$ 30.6$ billion. Note sales reached $\$ 29.9$ billion. Securrties Indus. Ass'n, Municipal Market Developments (table 4) (Feb. 1976).

4. As of the end of October, total new-issue municipal securities were selling at an annual rate of approximately $\$ 58$ billion. Long-term bond sales were $\$ 28.1$ billion through October, ahead of the 1975 volume, but note sales were only $\$ 19.2$ billion, showing a 23 percent reduction from the previous year's volume through that month. See Ryan, Note Sales Fall to $\$ 19.2$ billion in lst 10 Months, The Weekly Bond Buyer, Dec. 6, 1976, at 3. 
proposed legislation to regulate directly the disclosure practices of municipal issuers, and private actions challenging the legal sufficiency of past efforts at disclosure. The movement toward bringing the municipal securities market under direct federal supervision began with the creation in 1975 of the Municipal Securities Rulemaking Board to oversee the practices of dealers in municipal securities. ${ }^{5}$ Although the legislation that created the Board does not impose any actual disclosure duties upon municipal issuers, ${ }^{6}$ such a development appears to be forthcoming. Two proposals have been considered im Congress to extend the reach of the existing federal securities laws to cover municipal issuers. The level of regulation called for by the two bills differs substantially: one would impose all of the requirements of the Securities Act of 1933 on municipal issuers, ${ }^{7}$ while the other would require use of disclosure documents for new offerings and the filing of periodic reports specially designed for the municipal securities market. ${ }^{8}$

It is clear that in deciding what degree of regulation of issuers, if any, is required to insure the integrity of the municipal bond market, Congress should be aware of the present level of disclosure and the trend of disclosure practices. Empirical evidence demonstrating that municipalities are moving toward voluntary disclosure of most major items of material information associated with their bond issues should strengthen the argument for minimal regulation.

The same kind of evidence will be useful to courts faced with deternining whether the conduct of a particular municipal issuer constitutes a violation of the anti-fraud provisions of the federal securities laws. Investors have becoine increasingly aware of the availability of these provisions as a means of recouping losses incurred in municipal securities transactions. $^{9}$ In actions brought under section 17 of the

5. Securities Exchange Act of $1934 \S 15 \mathrm{~B}(\mathrm{~b})(1), 15$ U.S.C.A. $\S 780-4(\mathrm{~b})(1)$ (Supp. 1976).

6. Section 15B(d) of the 1934 Act, 15 U.S.C.A. $\$ 78 o-4$ (d) (Supp. 1976), added by the 1975 amendments, expressly prohibits the Municipal Securities Rulemaking Board from directly or indirectly requiring issuers to furnish information to investors or to the Board. This does not, of course, affect the issuer's obligations under the anti-fraud provisions.

7. S. 2574, 94th Cong., 2d Sess. (1976). The full texts of this bill and S. 2969 are reported in Hearings on S. 2969 and S. 2574 Before the Subcomm. on Securities of the Senate Comm. on Banking, Housing and Urban Affairs, 94th Cong., 2d Sess. 3-13 (1976).

8. S. 2969,94 th Cong., 2 d Sess. (1976). The two bills are analyzed in detail in Comment, Federal Regulation of Municipal Securities: A Constitutional and Statutory Analysis, 1976 DURE L.J. 1261, 1274-88.

9. At present there are at least fifteen cases involving municipal securities transactions pending throughout the nation. See Doty \& Petersen, The Federal Securities Laws and Transactions in Municipal Securities, 71 Nw. L. REv. 283, 297 n.71 (1976). 
Securities Act of $1933^{10}$ and rule $10 b-5,{ }^{11}$ promulgated under section 10(b) of the Securities Exchange Act of $1934,{ }^{12}$ attention will likely focus on the issuer's official statement, which provides information about the particular debt issue being offered as well as a history and overview of the issuer's financial and economic condition. ${ }^{13}$

The court reviewing the statement will first be required to determine whether the issuer has misstated or omitted any material fact with regard to the issue. ${ }^{14}$ The task of determining what facts are "material" poses considerable problems. The leading cases in the area of corporate securities approach the problein froin the viewpoint of the investor. In Affiliated Ute Citizens v. United States, ${ }^{15}$ for example, the Supreme Court defined as "Inaterial" all information which "a reasonable investor might consider in the making of [a] decision." 16 It is not, therefore, immediately apparent that the disclosure practices of municipal issuers in general are relevant to a determination of whether

10. It shall be unlawful for any person in the offer or sale of any securities by the use of any ineans or instruments of transportation or communication in interstate commerce or by the use of the mails, directly or indirectly-

(1) to employ any device, scheme, or artifice to defraud, or

(2) to obtain money or property by ineans of any untrue statement of a material fact or any omission to state a material fact necessary in order to make the statements made, in the light of the circunstances under which they were made, not inisleading, or

(3) to engage in any transaction, practice, or course of business which operates or would operate as a fraud or deceit upon the purchaser. Securities Act of $1933 \$ 17$ (a), 15 U.S.C. $\$ 77 q(a)$ (1970).

11. It shall be unlawful for any person, directly or indirectly, by the use of any means or instrunentality of interstate coinmerce, or of the mails, or of any facility of any national securities exchange,

(1) To employ any device, scheme, or artifice to defraud,

(2) To make any untrue statement of a material fact or to omit to state a material fact necessary in order to make the statements inade, in the light of the circumstances under which they were made, not misleading, or

(3) To engage in any act, practice, or course of business which operates or would operate as a fraud or deceit upon any person,

in connection with the purchase or sale of any security. 17 C.F.R. $\$ 240.10 b-5$ (1975).

12. Section $10(\mathrm{~b})$ makes it unlawful for any person

[t]o use or einploy, in connection with the purchase or sale of any security ..., any inanipulative or deceptive device or contrivance in contravention of such rules... as [the SEC] may prescribe .... Securities Exchange Act of 1934 \& $10(b)$. 15 U.S.C. \& 78j(b) (1970).

13. For a discussion of the traditional role and content of the municipal bond official statement see L. MOAK, AdMINISTRATION OF LOCAL GovernMENT DEBT 348-55 (1970); Securities Indus. Ass'n, Fundamentals of Municipal Bonds 84-98, 147 (1973).

14. See notes 10-11 supra.

15. 406 U.S. 128 (1972).

16. Id. at 153-54. The inateriality test was qualified somewhat in TSC Indus., Inc. v. Northway, Inc., 426 U.S. 438 (1976) in which the Court said that information in a proxy statement is material "If there is a substantial likelihood that a reasonable investor would consider it inportant in deciding how to vote." Id. at 449. 
a particular misstated or omitted fact was material to a particular investor. However, voluntary disclosure by issuers is, to a large extent, a response to a perceived investor demand for certain kinds of information. This is particularly true in the municipal securities market; it is dominated by banks and other mstitutional investors, which often have sufficient market leverage to force the disclosure of information they deem important. ${ }^{17}$ It could be inferred that information which is not normally disclosed is simply not considered important by nost investors, thus partially undercutting an anti-fraud contention that the investor's decision would have been different had he had the information. A knowledge of what facts mumicipal issuers normally disclose will therefore be of considerable probative value to a court in determining whether a particular omission was material.

Once the court has determined that a material fact has been misstated or omitted, it must then determine whether the issuer's conduct was sufficiently culpable to constitute a violation of the antifraud provisions. Recent Supreme Court decisions indicate that plaintiffs will be required to prove at least gross negligence or recklessness on the part of the issuer in order to recover. ${ }^{18}$ Under any standard of culpability short of absolute liability, however, the court will need to compare the defendant's conduct with that of others in its position. For example, the fact that an issuer failed to disclose a significant item of information that is routinely disclosed by a vast majority of municipal issuers would clearly tend to show at least negligence on its part. In addition, if it were shown that the item was included in a widely circulated list of suggested items for disclosure, the defendant's ormission could be inore readily cast as gross negligence. The main point, of course, is simply that courts venturing into the wholly new area of the disclosure responsibilities of municipal issuers will be interested in determining the market practice.

What follows are the results of a survey undertaken to determine what kinds of information municipal issuers are presently disclosing, and in particular the extent to which the Guidelines promulgated by the Municipal Finance Officers Association have become an accepted market standard.

17. As of the end of 1975 , banks held $46.1 \%$ of outstanding state and local securities; property and casualty companies owned $15.4 \%$; and households held $30.3 \%$. See J. Petersen, supra note 2, at 33-40.

18. Ernst \& Ernst v. Hochfelder, 425 U.S. 185 (1976). In Hochfelder, the Court held mere negligence to be an insufficient basis for an action brought under rule 10b-5; rather, something more closely akin to common law fraud must be shown. The question of whether gross negligence or recklessness will meet the Court's new standard remains open. See Doty \& Petersen, supra note 9, at 288-89 n.24. 


\section{Measuring Municipal Disclosure}

Although adequacy of credit information supplied to the municipal bond market is a major policy issue, until recently there have been no systematic studies of the actual disclosure practices of state and local governments. This section reports on a study undertaken to measure the level of disclosure by sampling the documents (official notices of sale, offering statements, or prospectuses) that accompanied debt issues offered by local governments in the fall of 1975 and spring of 1976. Because most municipalities do not regularly distribute annual reports to bondholders, ${ }^{10}$ the information made available by the issuer at the time of sale is likely to be a particularly important form of communication to investors.

Of course, there are many and diverse sources of infornation relevant to judging credit quality. The national and local news media are undoubtedly important as providers of credit-related data. Agencies of the federal and state governments and the rating agencies also supply relevant infornation. Most of these sources are readily available at nominal cost to investors. Furthermore, the bond's interest rate itself represents the market's judgment of its relative worth, and therefore serves as an indicator of quality to the individual imvestor. But the issuer's official statement or prospectus is the document that provides the single most comprehensive and original source of information.

Because of the obvious concern over disclosure in the municipal market and the concerted effort of many to upgrade the level of reporting (as witnessed by the Guidelines), the research effort was designed to permit a comparative study of reporting practices over time. ${ }^{20}$ An initial survey of offering statenients was conducted in October and November of 1975; a second sample was compiled for new issues sold

19. A factor contributing to the lack of distribution of annual reports is that most municipal bonds are sold in bearer form and the issuer does not keep a register of security holders.

20. The original program of research sponsored by the Municipal Finance Officers Association contemplated a survey of municipal bond offering statements to be performed during 1975. As the "disclosure problem" gained momentum in the municipal market, it gave concomitant impetus to the possibility of federal intervention and regulation of that market. These developments added new importance to this project. A major premise underlying the necessity for direct federal control of disclosure information was the notion that existing practices did not meet investor needs and that market forces would not be able to provide the incentive for improved credit reporting. However, the evidence on municipal market disclosure practices was largely impressionistic and anecdotal, with no scientific or systematic study of what items of information were, in fact, being distributed in official statements. See Hearings on Municipal Securities Full Disclosure Act of 1976 Before the Subcomm. on Securities of the Senate Comm. on Banking, Housing and Urban Affairs, 94th Cong., 2d Sess. 52 (1976). 
in May and June of 1976. Comparison of the results of the surveys permits examination of the extent to which reporting practices changed in response to the new (and sometimes hostile) market environment that faced municipal issuers during the period.

The survey periods selected encompass the most dramatic and profound events in the market for many decades, starting at the apex of the New York City crisis and ending with the successful spring financing of New York State. During most of this six-month interval, the municipal bond market was preoccupied with weekly and sometimes daily "cliff-hangers." It was not a period conducive to leisurely contemplation of the longer-run import of events. The survey, then, is best viewed as capturing short-run reactions to the disclosure problem -rapidly adjusting old procedures to meet newly perceived and still uncertain requirements in the market.

\section{The Survey Sampling Procedure}

The initial step in evaluating municipal bond disclosure practices was to develop a sampling procedure for compiling representative bond offering statements. The samples were selected in the following manner.

For the fall 1975 sample, all issuers or fiscal advisors who announced pending bond sales in the Thursday and Friday editions of The Bond Buyer, "Sealed Bids Invited" section, were contacted by letter (when sufficient address information was provided). This procedure was carried out froin September 25 through November 20. Other than the availability of address information, no further screening of the sample issues was performed. This procedure was designed to assure that a representative sample of competitively offered tax-exempt issues would be obtained. Requests were mailed to 297 issuers, and 238 responses were received. Because of limited resources no follow-up of nonrespondents was attempted. However, all of the nonrespondents were offering issues of less than $\$ 5$ million.

For the spring 1976 sample, the same basic procedure was followed, except that issues were selected from the bids-invited listings in The Bond Buyer on a daily basis for the month of May. ${ }^{21}$ Two liundred twenty-eiglit requests were mailed and 194 responses were received.

21. Note that the sample is restricted to competitively offered securities; it does not include negotiated sales. It is reasonable to assume that the prospectuses accompanying negotiated issues that are reoffered are typically more extensive. If this is so, then the sample perhaps understates the amount of reporting that is characteristic of this segment of the market.

On the other hand, many issuers who expect to reach only a local market do not 
From the overall sample response, only those official statements pertaining to local governmental general obligation offerings were selected for examination. This was done in order to achieve as much uniformity as possible in the types of instruments and offerings to be examined, and because the general obligation security appears to present particular disclosure problems for the market. ${ }^{22}$ The survey of local governmental general obligation issues contamed 176 issues in the 1975 sample and 129 issues in the 1976 sample and appeared to be reasonably representative of the types of local government issues offered in the municipal bond market. ${ }^{23}$ The majority of offering statements were associated with small issues of less than $\$ 2.5$ million, including one issue of only $\$ 90,000$.

After the compilation of the sample, the next step in the analysis required the development of a standard of informational content for evaluating the extent of disclosure im the offering statements. This was accomplished by establishing an inventory of credit information items based on those items recommended for disclosure in the guidelines issued by the Municipal Finance Officers Association. ${ }^{24}$ Forty-two

advertise in The Weekly Bond Buyer. These issuers typically provide less information than those interested in regional or national markets. In this respect the sample may overstate the amount of reporting.

22. General obligation bonds give rise to several difficult disclosure problems. In the first place, purchasers of these obligations are likely to demand less information than purchasers of more specialized bonds since the bonds appear to be secured by a variety of revenue-raising options. This type of security will also make it difficult for a disappointed investor seeking redress under the anti-fraud provisions to convince a court that any one fact was material with regard to his decision to purchase the bonds.

In fact, however, general obligation bonds may not always be as secure as they appear. In spite of their status as secured creditors, bondholders may be given low priority in the distribution of the revenue of a financially troubled municipality, and their demands may be subordinated to the need to maintain services. See Note, Creditors' Remedies in Municipal Default, 1976 Duke L.J. 1363, 1382. In addition, some courts have tended to allow municipalities considerable flexibility in re-arranging creditor priorities in financial emergencies to the point of justifying the abrogation of debt contracts as an exercise of the municipality's police powers. See Comment, The Role of the Contract Clause in Municipalities' Relations with Creditors, 1976 DUKE L.J. 1321, 1338. 52.

A final problem for purchasers of general obligation bonds is the necessity to comprehend the governmental unit's accounting system in order to assess the quality of the offering. Typically, such systems stress data which the issuer is required to report to other units or which is necessary for internal control of funds, and are not designed primarily to present clearly the municipality's overall financial condition. See Doty \& Petersen, supra note 9, at 336-40.

23. The issuers involved in the fall 1975 sample included 27 counties, 40 school districts, and 101 cities, towns or townships. In the spring 1976 survey, the figures were 20,43 and 61 respectively. The average size of the issues was $\$ 3.4$ million in the 1975 sample and $\$ 4.3$ million in the 1976 sample.

24. Guidelines. The Guidelines project represents a major self-regulatory effort on the part of municipal issuers. It was funded by a grant from the National Science Foun- 
separate items of information, listed in Table 1 and explained in more detail in the Appendix, were used to evaluate the official statements. This inventory of information, while perhaps not sufficient for full disclosure in every case, nonetheless seemed to include those items the omission of which might raise questions as to the adequacy of the disclosure in the official statement.

The resulting inventory of individual credit information items was divided into four major categories:

1. Financial Report Information - the existence and form of financial statements presented, accounting methods used and auditing opinions;

2. Revenue Information-property tax base, assessment policies, rates and collections, tax restrictions and other revenue sources;

3. Debt Information - bonded debt outstanding, debt service requirements, debt margin and restrictions, short-term debt, overlapping debt, bondholder protections and employee pension liabilities;

4. Demographic, Economic and Governmental Informationpopulation levels and trends, imcome, economic structure and activity, employment, structure and services of the borrowing governmental unit.

The documents were taken at face value. The existence or absence of an informational item was simply noted on an examination form. No effort was made to contact issuers to clarify items or gain added information. No qualitative judgments were made as to the accuracy of items or their materiality to a particular offering. On the other hand, the statements were carefully reviewed within the context of specific decision rules developed to guide the compilation of the inventory. Information in both tabular and narrative form was credited in the imventory. Additional detail on procedures is presented in the Appendix.

dation and involved the participation of representatives from all sectors of the municipal bond market. The "exposure draft" of the Guidelines was given broad distribution. As of September, 1976, over 4,000 copies of the Guidelines had been distributed, almost all of them on request. See Hearings on H.R. 15205 Before the House Subcomm. on Consumer Protection and Finance, 94th Cong., 2d Sess. 1210 (1976) (statement of Municipal Fin. Officers Ass'n). In addition, the Guidelines became the focal point of discussion among members of the industry, particularly at the conferences on disclosure sponsored by the MFOA im Los Angeles, Washington, Chicago, Denver, Boston, Atlanta and San Francisco. In March, 1976, two committees were formed to consider revision of the Guidelines in light of the various discussions and written comments, and in December of 1976, a second draft was approved by the Executive Board of the MFOA.

The inventory of disclosure items used in the survey reported below was taken from the "exposure draft" of the Guidelines which is the version referred to throughout this Article. 


\section{TABLE 1}

INVENTORY OF DISCLOSURE ITEMS BY

MAJOR CATEGORY

\section{Financial Report Information}

1. Current and detailed operating statement

2. Operating statement for prior years

3. Basis of accounting used

4. Financial statement audited

5. Current "Pro forma" or budget statement

6. Detailed balance sheet

7. Balance sheet for prior years

8. Contingent liabilities (or lack thereof)

\section{Revenue Information}

1. Current-year assessed property value

2. Assessed value for prior years

3. Current market value of property

4. Market value for prior years

5. Composition of assessed property

6. Method of assessment discussed

7. Current real property tax rate

8. Tax rates for prior years

9. Tax collection (or dehinquency) rate

10. Tax collection rate for prior years

11. Policy toward tax collections

12. List of "top ten" taxpayers

13. Discussion of intergovernmental programs

14. Property tax limits (or lack thereof)

\section{Debt Information}

1. Current direct bonded debt

2. Direct debt for prior years

3. Authorized but umssued debt

4. Future debt service requirements

5. Current overlapping debt

6. Discussion of debt limitations

7. Calculation of unused debt capacity

8. Nature of short-term debt (or lack thereof)

9. Legal rights of bondholders

10. Description of employee pension plan

Demographic, Economic, and Governmental Information

1. Population of issuer

2. Population trends

3. Per capita or other income

4. Unemployment rate

5. Description of economic base and activity

6. List of principal firms or employers

7. Information on building permits

8. Discussion of goverming body and key officials

9. Discussion of governmental services 


\section{Survey Results}

The results of the analysis of the inventory of items for each of the major categories of information are displayed in Tables 2, 3, 4 and 5. Within each category, the table gives the average reportmg rate for the total of items contained in the category, which may be viewed as a summary statistic or index of the overall level of reporting or disclosure for that block of information. ${ }^{25}$ For purposes of this analysis, each individual iten and official statement has been treated as equally important; thus all the average rates reported are simple rather than weighted averages. Table 6 gives the averages for the four inajor blocks of information and an overall total for each of the two surveys.

The results of the two surveys are examined by the major categories of informational items:

\section{Financial Report Information}

The MFOA Disclosure Guidelines stress the importance of presenting in the official statement the appropriate financial statements needed to indicate the issuer's overall condition and ability to meet its debt. The Guidelimes suggest that these be selected in accordance with generally accepted accounting principles and that they be accompanied by the opinion of an independent auditor, either private or public. $^{26}$ Both operating and balance sheets for current and prior years are recommended for presentation. ${ }^{27}$

As is displayed in Table 2, several major items of financial mformation were not contained in a large number of the official statements collected in the fall of 1975 . In fact, only a current detailed operating statement was found in a sizable share of official statements (47 percent), and not one contained balance sheets. The overall percentage of disclosure of the eight major items was only 14.0 percent, and few issuers even bothered to state the basis of accounting used.

25. An alternative formulation would be to measure the level of disclosure per dollar of debt offered as opposed to per offering. With this method, each item of the inventory would be weighted by the dollar value of debt offered under each official statement examined. The average would be calculated by dividing that total by the total amount of debt sold. Since improvement in the level of disclosure was greatest in larger issues (see Table 8 infra), the improvement in disclosure on a per-dollar basis was undoubtedly greater than that calculated on a simple numerical average of the official statements.

26. GUIDELINES 3-4.

27. Id. at 5. The Guidelines recommend the presentation of operating statements for each of the last five fiscal years. However, the Guidelines also state that where five-year disclosure is called for, three-year series may suffice if the additional years would display no significant difference in trends. Id. at 3. 
The dismal level of reporting financial information changed markedly in the following six months. The spring 1976 survey revealed large improvements in every item of information. A majority of the official statements contained detailed current and historical operating statements, and the percentage of audited financial statements had risen from 6 percent to nearly 33 percent. Despite the strength of the trends in reporting, however, six of the eight items were still being reported in less than half of the official statements.

TABLE 2

FINANCIAL REPORT INFORMATION

Percentage of Official Statements Containing Items

Items reported:

1. Current and detailed operating statement

2. Operating statement for prior years

3. Basis of accounting used

4. Financial statement audited

5. Current "Pro forma" on budget statement

6. Detailed balance sheet

Survey:

7. Balance sheet for prior years

8. Contingent liabilities (or lack thereof)

Average percentage of items reported

$\begin{array}{cc}\text { Fall '75 } & \text { Spring '76 } \\ 46.6 & 76.0 \\ 34.1 & 66.7 \\ 5.7 & 34.1 \\ 6.2 & 32.6 \\ 11.9 & 34.9 \\ 0.0 & 31.8 \\ 0.0 & 18.6 \\ 7.4 & 41.1 \\ 14.0 & 42.0\end{array}$

\section{Revenue Information}

The MFOA Guidelines recommend that various aspects of the local revenue system - basically those items in Table 3-be considered for presentation in the official statement. ${ }^{28}$ As can be seen, official statements in the fall 1975 survey showed a high level of reporting of aggregative items such as taxable property value (assessed and market values), tax rates, limits, and collection information. Much of the detail and process inforination was lacking, however. The spring survey showed minor improvements in the presentation of prior year information, ${ }^{20}$ and inore discussions of the procedures used in setting and collecting taxes (items 6 and 11). Remaiming at low levels of reporting were discussions of the composition of taxable property and intergovernmental payments. The latter item can be of substantial importance, especially to school districts, which receive an average of 46 percent of their annual revenues in the form of intergovernmental assistance payments. ${ }^{30}$ Overall, official statements in spring

28. Id. at 8-9.

29. Examination of underlying responses shows that the large majority (about 90 percent) of those giving prior year information give it for the preceding four or five years.

30. U.S. Bureau of the Census, Governmental Finances in 1972-73, at 30 
1976 disclosed 66 percent of the listed revenue-related items as opposed to 60 percent six months earlier.

TABLE 3

\section{REVENUE INFORMATION}

Percentage of Official Statements Containing Selected Items

Items reported:

1. Current-year assessed property value

2. Assessed value for prior years

3. Current market value of property

4. Market value for prior years

5. Composition of assessed property

6. Method of assessment discussed

7. Current real property tax rate

8. Tax rates for prior years

9. Tax collection (or delinquency) rate

10. Tax collection rate for prior years

11. Policy toward tax collections

12. List of "top ten" taxpayers

13. Discussion of intergovernmental payments

14. Property tax limits (or lack thereof) Average percentage of items reported

\begin{tabular}{cc}
\multicolumn{2}{c}{ Survey: } \\
Fall '75 & Spring '76 \\
98.3 & 98.4 \\
88.6 & 92.2 \\
72.7 & 84.5 \\
30.7 & 46.5 \\
18.2 & 17.8 \\
24.4 & 32.6 \\
77.3 & 78.3 \\
68.7 & 71.5 \\
94.3 & 96.9 \\
92.0 & 96.1 \\
30.1 & 51.9 \\
60.2 & 66.7 \\
4.0 & 14.7 \\
82.4 & 77.5 \\
60.1 & 66.1
\end{tabular}

\section{Debt Information}

The disclosure guidelines call for the disclosure of the bonded debt figures and a discussion of how these interrelate to the issuer's debt limits, debt service requirements, and unused debt margin. ${ }^{31}$ In addition, less frequently disclosed items sucl as short-term (or floating) debt, bondholder rights, and the status of employee pension funds are also suggested for disclosure. ${ }^{82}$

As Table 4 indicates, most official statements in the fall of 1975 disclosed the current value of debt owed by both the issuer and overlapping units, and a majority set out future debt service requirements. However, little disclosure was made of the authorized but unissued debt, debt limits, remaining debt capacity or short-term debt. And only a few of the official statements discussed bondholder rights, the pension plans, or the issuer's debt history.

By the spring of 1976 , disclosure in every area except current

(1974). This is approximately the same percentage of their revenues as comes from local property taxes. These two sources, therefore, account for 92 percent of all school district revenues.

31. GUibelines 6-7.

32. Id. at 7.8. 
direct bonded debt had risen markedly. Of the ten items listed, authorized but unissued debt, prior years' outstanding debt, and legal rights of bondholders continued to be disclosed in a minority of offering docuinents, but the other inventory items were being disclosed in approximately one half or more of the official statements. Particularly noteworthy was the leap in discussions of employee pension plans. ${ }^{33}$ The total percentage of items being disclosed increased from almost 34 to over 53 percent during the winter months of 1975-76.

TABLE 4

\section{DEBT INFORMATION}

Percentage of Official Statements Reporting Selected Items

Items reported:

1. Current direct bonded debt

2. Direct debt for prior years

3. Authorized but unissued debt

4. Future debt service requirements

5. Current overlapping debt

6. Discussion of debt limitations

7. Calculation of unused debt capacity

8. Nature of short-term debt (or lack thereof)

9. Legal rights of bondholders

10. Description of employee pension plan Average percentage of items reported

\begin{tabular}{cc}
\multicolumn{2}{c}{ Survey: } \\
Fall '75 & Spring '76 \\
97.2 & 93.8 \\
9.1 & 17.8 \\
22.7 & 31.8 \\
55.7 & 79.8 \\
86.4 & 92.2 \\
23.9 & 51.2 \\
15.3 & 45.0 \\
18.2 & 48.1 \\
2.8 & 16.3 \\
4.5 & 55.8 \\
33.6 & 53.2
\end{tabular}

\section{Demographic, Economic, and Governmental Items}

The Guidelines recommend the presentation of several items of general descriptive information that inay be of use to investors in general obligation bonds in particular. Most important among these are population, income, and such economic activity measures as unemployment rates, principal sources of employment, and building activity. ${ }^{34}$ The Guidelines also suggest a discussion of governmental services $^{35}$ and a description of the issuer's governing body and executive officials. ${ }^{36}$

In the past, such descriptive information, often illustrated, lengthy and glowing, has been a hallmark of local government prospectuses.

33. It should be noted that a majority of local governments do not operate their own pension systems; their employees are members of state plans. See R. Tilove, Public EMployee Pension FundS 5-6 (1976).

34. Gumelines 10-11.

35. Id. at 11 .

36. Id. at 14 . 
In the fall of 1975 , the official statements sampled generally reported population and principal employers, and most discussed economic activity. However, for the nime items listed in Table 5, the overall average rate of disclosure im the fall 1975 survey was less than 45 percent. Income figures and unemployment rates (both of which may be unavailable for many jurisdictions) ${ }^{37}$ were reported im only 15.9 and 5.1 percent respectively of the official statements.

As was true with the other major categories, improvements im reporting were sizeable and widespread, with the overall average level of reporting improving to 58 percent of the items. If the mcome and unemployment data, which probably are not obtainable for many smaller issuers, are extracted, the average reporting rate would have been 67.2 percent in spring 1976. Still, much information that is readily available to the issuer, such as building permit activity and descriptions of the governing body, was presented less than half of the time.

\section{TABLE 5}

\section{DEMOGRAPHIC, ECONOMIC, AND GOVERNMENTAL INFORMATION}

\section{Percentage of Official Statements Containing Selected Items}

Items reported:

1. Population of issuer

2. Population trends

3. Per capita or other income

4. Unemployment rate

5. Description of economic base and activity

6. List of principal firms or employers

7. Information on building permits

8. Discussion of goverming body and key officials

9. Discussion of governmental services Average percentage of items reported
Survey:

$\begin{array}{cc}\text { Fall '75 } & \text { Spring '76 } \\ 79.0 & 89.1 \\ 52.8 & 61.2 \\ 15.9 & 29.5 \\ 5.1 & 23.3 \\ 61.9 & 74.4 \\ 79.0 & 88.4 \\ 29.5 & 49.6 \\ 31.8 & 45.0 \\ 48.3 & 62.8 \\ 44.8 & 58.1\end{array}$

\section{Overall Disclosure Levels}

As Table 6 mdicates, the overall level of disclosure in the sample of local government general obligation official statements showed a substantial improvement between the fall and spring surveys, as measured by the forty-two key-item inventory. By the spring of 1976 the average level of disclosure in all of the categories had risen.

37. See Appendix (Part I.D.). 


\section{TABLE 6}

TOTAL INFORMATION DISCLOSED

Average Percentage of Official Statements

Containing Selected Items by Major Category

Category of Information:

Financial report

Revenue

Debt

Demographic, economic and governmental Average percentage for 4 categories
Average Percentage Percent of Reporting Increase

Fall '75 Spring '76 '75 to '76

$14.0 \quad 42.0 \quad 200 \%$

$60.1 \quad 71.4 \quad 19 \%$

$33.6 \quad 53.2 \quad 58 \%$

$44.8 \quad 58.1 \quad 30 \%$

$38.1 \quad 56.2 \quad 48 \%$

If each major category of information is weighted equally, the overall average reporting level rose from 38.1 percent to 56.2 percent. $^{38}$ More importantly, the sharpest improvements were registered in those categories where the reporting had been the lowest in the fall survey. For example, in rising from a reporting average of 14 percent to 42 percent, financial report items scored an impressive 200 percent improvement. On the other hand, the revenue category, which had shown a relatively high average disclosure level in the fall survey, experienced a smaller proportionate increase of 19 percent in the average number of items reported. Much improvement is still possible among the items selected for the imventory. In particular, reporting of sufficient historical data to determine trends is still being done in only a minority of cases. ${ }^{30}$ Nonetheless, the official statements of local governments showed a dramatic change in the direction of fuller and more balanced disclosure.

\section{Disclosure and Issuer Characteristics}

It is useful to observe how the levels of disclosure and changes in disclosure practices as neasured by the inventory are associated with various issuer characteristics. Table 7 relates the average levels of reporting to the rating given to the bond issue by Moody's Investor service for both the survey periods. In the fall 1975 survey, the average level of disclosure was unrelated to the rating. Disclosure in the

38. Were each of the forty-two underlying items weighted equally to form an index, the average for the revenue information would account for 35 percent of the total average disclosure; debt factors for 24 percent; economic factors for 21 percent; and financial report information for 20 percent. Since the individual items of information may themselves be multi-dimensional and often have no relevancy when taken in isolation, there seems to be no a priori reason not to treat the category averages as aggregates and to weigh them equally in devising a total as we have done in Table 6.

39. Prior-year operating statements, balance sheets, taxable market values, and direct debt were being reported in less than half the official statements. 
highest rating category of Aaa was lower than that for two lesser ratings. Six months later, however, there was a positive correlation between the rating category and the average level of reporting. The improvement was particularly noteworthy in the two highest grades, Aaa and Aa.

\section{TABLE 7}

AVERAGES OF OVERALL DISCLOSURE BY MOODY'S RATING

Average Percentages of Reporting of Overall Information

(Number of Issues in Parentheses)

$\begin{array}{lcc}\text { Rating } & \text { Fall '75* } & \text { Spring '76 } \\ \text { Aaa } & 41.1 & 66.7 \\ & (12) & (3) \\ \text { Aa } & 41.5 & 59.4 \\ & (34) & (27) \\ \text { A-1 } & 39.9 & 53.5 \\ & (42) & (25) \\ \text { A } & 42.1 & 51.9 \\ \text { Baa } & (62) & (53) \\ & 36.3 & 51.4 \\ & (25) & (21)\end{array}$

* The 1975 sample included one unrated bond issue (disclosure average was 35.7). There were no unrated issues in the 1976 sample.

Table 8 displays another positive association, in this case between the average level of disclosure and the size of the bond issue (which is usually directly related to the size of the issuer). Although improvements in reporting occurred throughout the range of issue sizes, the greatest increases were achieved in the largest issues. In particular, issues exceeding $\$ 10$ million, for which slightly less than half the inventory items were reported during the 1975 survey, reflected a dramatic increase to greater than 70 percent disclosure in the 1976 survey.

TABLE 8

\section{AVERAGES OF OVERALL DISCLOSURE BY SIZE OF BOND ISSUE}

Average Percentages of Reporting of Overall Information Items (Number of Issues in Parentheses)

$\begin{array}{lcc} & \text { Fall '75 } & \text { Spring '76 } \\ \text { Less than \$1 million } & 36.1 & 44.7 \\ & (76) & (46) \\ \text { \$1 million to \$5 million } & 42.4 & 54.9 \\ \text { \$5 million to \$10 million } & (69) & (60) \\ \text { Over \$10 million } & (19) & 68.3 \\ & 47.1 & (8) \\ & (12) & 71.0\end{array}$


Table 9 presents a geographic breakdown of the reporting levels found in the surveys. Again, the level of reporting in all areas increased substantially during the survey period. In the fall of 1975 average regional reporting levels were between 36 and 48 percent, thus evidencing a high degree of unifornity across the nation. Six months later in the spring of 1976, however, the regional disclosure levels ranged from 45 percent in the North Central region (which showed the lcast improvement in reporting levels) to almost 78 percent in the Northeast region (which showed a 116 percent increase in its average level of reporting).

TABLE 9

AVERAGES OF OVERALL DISCLOSURE BY REGION

Average Percentages of Reporting of Overall Information (Number of Issues in Parentheses)

$\begin{array}{lcc}\text { Region } & \text { Fall '75 } & \text { Spring '76 } \\ \text { Pacific } & 44.4 & 50.4 \\ & (12) & (19) \\ \text { Mountain } & 40.3 & 58.2 \\ & (15) & (13) \\ \text { North Central } & 39.1 & 45.4 \\ & (84) & (52) \\ \text { South and Southeast } & 38.1 & 57.0 \\ & (34) & (15) \\ \text { Middle Atlantic } & 48.2 & 61.6 \\ & (16) & (17) \\ \text { Northeast } & 36.0 & 77.8 \\ & (15) & (13)\end{array}$

The apparent reason for this divergence in regional reporting levels was the investors' concern over the credit of eastern municipalities and the relative lack of worry about those im the western regions of the country. Whatever the other causes, it was clear evidence that the market was effective in demanding a higher level of disclosure from those Northeast local governinent borrowers that only six months before had been able to go to market with the least information.

\section{Legal Implications of the SuRvey}

There are many possible reasons for the improved disclosure policies of municipal bond issuers which were revealed by the survey results. The most obvious of these are the desire on the part of the issuers to avoid liability under the anti-fraud provisions and to forestall direct federal regulation and, of course, their desire to sell bonds. ${ }^{40}$

40. See, for example, the statement of Philip T. Smith, Jr., a partner in the invest- 
In any event, it is evident that there was an increase in the level of disclosure between fall 1975 and spring 1976 of those items of information recommended for disclosure by the MFOA Guidelines, and it may well be that the Guidelines are gradually coming to be viewed by the market as an authoritative standard for disclosure. ${ }^{41}$

What, then, is the legal significance of this development? Regardless of the level of acceptance of the Guidelimes, a failure to comply with every suggestion will not, of course, give rise to an automatic securities law violation. Even after identifying an omission, the court will still need to make an independent finding that the item of inforination was material with regard to the particular bond issue. ${ }^{42}$ Nevertheless, the Guidelines should be of great value to anti-fraud plaintiffs and defendants in that they comprise a comprehensive inventory of information items that should be disclosed in most instances. In fact, it is not difficult to envision a situation in which, in spite of the plaintiff's burden of proof, a municipal issuer will find itself having to justify a departure from the Guidehines. ${ }^{43}$

Several valid justifications for departure are available. An obvious reason would be that the particular data are not material under the circumstances. The flexibility to omit irrelevant information is inportant if investors are not to be burdened with a profusion of unneeded information and unreadable documents, thereby defeatimg the purpose of disclosure. Another reason that is likely to be asserted frequently is the unavailability of material called for by the Guidelines. For example, a school district may not be able to obtain accurate

ment banking firm of Kuhn, Loeb \& Co.: "If issuers don't supply the information we need on general obligation bonds, then we won't make bids on them and investors won't buy them." Bond Buyers Wanted Fuller Disclosure, BusINEsS WEEK, June 23, 1975, at 77.

41. The utility of the Guidelines as a standard for municipal disclosure has been noted by several commentators. See, e.g., Hearings on S. 2969 and S. 2574, supra note 7, at 28-29 (remarks of SEC Chairman Roderick M. Hills); SUBCOMM. ON CONSUMER Protection and Finance of the house Comm. on Interstate and Foreign ComMERCE, 94th Cong., 2d Sess. (1976) (statement submitted by Harold Steinberg).

42. See notes 14-16 supra and accompanying text. The Guidelines recognize the vagueness and ambiguity of the materiality concept in the anti-fraud provisions. As the Preface to the Guidelines states:

These Guidelines suggest disclosure of information that is most likely to be material to investors. It is possible that other information, not suggested herein, may at times be material and im such cases should be provided. . . . In some cases certain specific suggested information will not be material under the circumstances. In such instances, there is no need to report the information. Guidelines 2.

43. Because of the comprehensiveness of the Guidelines, plaintiffs may reasonably be required to carry a heavier practical burden in asserting the materiality of information not suggested for disclosure in the Guidelines. 
population figures since government census data are normally broken down only by counties or standard metropolitan statistical areas. Even if the figures are presented in terms of the political subdivision wishing to issue bonds, the data may be available only for prior years. In situations such as these, the issuer's inability to supply the information recommended by the Guidelines should therefore be disclosed. ${ }^{44}$

Finally, the extent to which a failure to comply with the disclosure guidelines will amount to sufficient neghigence to constitute an antifraud violation remains to be determined. For example, the survey indicates that the percentage of issuers which are obtaining imdependent audits of their financial statements as recommended by the Guidelines increased froin 6 percent to 33 percent between fall 1975 and spring 1976. Failure to einploy an independent auditor in view of this trend could be an indication of a lack of due care on the part of the issuer. Yet, at the same time, it would be difficult to classify as grossly negligent a practice engaged in by two-thirds of the municipal issuers. The most that can be said at this point is that the reviewing court will be in a better position to assess the conduct of the defendant issuer if it has available evidence showing the market practice.

\section{CONCLUSION}

As legislatures and the judiciary develop additional rules to govern the conduct of municipalities engaged in the offermg of debt, it is essential that they be apprised of the current practices in that inarket. The surveys reported on in this Article were undertaken in an effort to meet this need. The finding that the overall level of voluntary disclosure has increased dramatically over the past year, largely in those areas recommended by the MFOA Guidelines, should provide support for those advocating a scheme of governmental regulation less stringent than that imposed upon corporate issuers. At the same time, the survey results should be of use to courts in determining whether a particular issuer's conduct constituted a violation of the presently applicable anti-fraud provisions of the securities laws.

Nevertheless, the two surveys are by no means an adequate empirical basis upon which to begin the formulation of definitive rules. Other areas need to be explored; for example, a survey of the actual informational desires of investors would be extremely valuable in deter-

44. The omission of the specific data should be permitted under such circumstances, however, as is the practice in the corporate market. See SEC Rule 409, 17 C.F.R. $\S 230.409$ (1976). 
mining which facts are material in a particular context. The municipal bond market's high level of responsiveness to changing conditions, as reflected by the survey results, indicates that strong self-regulatory pressures are already at work. Those charged with imposing additional restrictions on municipal issuers, therefore, would be warranted in proceeding with caution until additional information is available which will show whether the current trend is a temporary response to the publicity surrounding the New Yrork City crisis or a more deeply rooted assumption of responsibility. 


\section{APPENDIX}

\section{EXPlanation OF ITEMS USED IN Disclosure INVENTORY}

\section{A. Financial Report}

\section{Financial Statements (general characteristics)}

A financial report consists of the financial statements, which are formal presentations of the financial records of the unit as expressed by its accounting system, as well as any additional information needed to provide an accurate report on its conduct and condition. The accounting systems used by municipalities (cities, school districts, states, special districts, etc.) are based on the fund concept. A fund is an autonomous unit with a revenue or asset source that must be used in prescribed ways, or at least in ways that inure to the general welfare. The emphasis in fund accounting, therefore, is on the fiduciary relationship between the managers or fund-users and their constituents (taxpayer-voter). Under this concept of resource accountability by funds, the balance sheet shows the resources available at a point in time, while the operating statement shows resource allocation over time. Government entities use a number of funds to record revenues and expenditures. The general fund typically is used to record the receipt of revenues that may be used for general purposes and expenditures used in the general operations of the unit. A number of special funds are also used, such as debt service, special assessment, trust, agency, capital, and project funds. Each of these funds has the same general characteristics. They are autonomous and selfbalancing (within the fund, assets equal equities). They differ from the general fund in that they have been set up for a specific or restricted purpose and they frequently are not available for general purpose use.

\section{Audited Report}

Audits result in expert opinions that the financial statements fairly present financial position and are in conformance with the applicable accounting principles. They are generally evidenced by an indication in the prospectus that an accountant audited the statement and issued an opimion or that a state agency audited the statements and issued an audit report.

\section{Accounting Method}

This is a specific statement contained in the prospectus as to the method of accounting used by the issuer (cash, modified accrual, or accrual method). There was no attempt to infer from the statements in the samples what method was being followed.

\section{Operating Statement}

This is a statement of revenue and expenditures which shows allocation of resources over time. Some issuers prepare these statements fund by fund; 
others consolidate all funds into a single statement, making no distinction between restricted and unrestricted revenues. Although a coinparison of budgeted to actual operating revenue and expenditures is inost desirable, the survey looked only to the pro forma inclusion of information on budgeted expenditures versus revenues for the current year. It was expected that the operating statement, whether prepared by funds or consolidated, would provide detail on the various revenue sources and the various broad categories of expenditures.

\section{Balance Sheet}

This is a statement of the assets and equities of the issuer. The equity side of the balance sheet lists the liabilities (debt, etc.) and the fund balance. It may be prepared on a fund-by-fund or a consohdated basis. A consolidated balance sheet aggregates all assets (these should be classified as restricted or unrestricted) and all liabilities of all funds into one balance sheet.

\section{Contingent Liabilities Reported}

Law suits pending against the issuer should be reported in notes to the financial statement or in the financial statement itself, except where there is little likelihood the issuer will pay the judgment. The absence of such liabilities should be noted.

\section{B. REVENUE INFORMATION}

\section{Assessed Property Value}

This is a statement of the value used by the municipality in subjecting realty and personal property to taxation. The assessed value is usually less than the market value of the property.

Property assessment is generally handled by local governments. The tax of an overlying political jurisdiction (county or state) may therefore be applied to a number of different local assessment systens. To equalize the effect of a single overlying tax rate on various assessment systems, an equalization rate is used. A single agency (generally at the state level) sets the equalization rate so as to bring the differently assessed values of property in each town, etc., into a rough equahty, allowing a county-wide tax rate to be applied.

\section{Market or True Value}

Market value is generally a measure of the true or sales value of property. However, because of delays in collecting the infornation and other factors, the figure in the official statement inay only approximate actual market value. 


\section{Composition of Assessed Valuation}

This is a breakdown of real property assessment by type (i.e., residential, industrial, commercial). Often included in this statement is some measure of the assessed value of properties in political subdivisions that are exempt from taxation.

\section{Changes in Assessment Methods}

Cities, towns, counties, etc., are often required by court order to use more equitable systems of assessment. A move to full or fair value is underway. A change of this type should be disclosed, as should assessment procedures in general.

\section{Real Property Tax Rate}

A tax rate expressed either in mills $(1 / 10$ of a cent per dollar of assessed value) or in dollars (per thousand) is generally used to calculate the taxes due on each piece of property.

\section{Tax Collection Rate}

This is the percentage of the taxes levied that has been collected. The time at which the percentage is calculated may vary. One percentage calculation used is that for the tax due date; another is that for the close of the fiscal year. The collection percentage should rise between these dates. The issuer should disclose when the percentage was calculated. This rate may also be shown as a tax delinquency rate.

\section{Tax Collection Policy}

The prospectus should contain a discussion of steps taken to collect delinquent taxes and give some indication of the effectiveness of this policy, which may involve tax foreclosure proceedings or other legal actions. The dollar amount of delinquent taxes should be disclosed.

\section{Listing Top Ten Taxpayers}

This list indicates the dependency of issuer revenues on inajor taxpayers. The investor may use it to assess the degree of credit risk, as in the case where tax receipts are highly concentrated in one industry.

\section{Source of State Aid Payments}

School districts and other issuers usually receive payments from the state based on some formula (school attendance, population, retail sales, etc.). The amount, sources and nature of these payments should be disclosed. 


\section{Real Property Tax Limits}

A limit on the ad valorem real property tax rate may be set by charter, state statute or constitution. This limit restricts the issuer's real property taxing ability to some percentage of the assessed or full valuation. (Debt service is often excluded from this limit, sometimes because it is constrained under separate debt restrictions.) Any limits on taxes and restrictions on their use should be noted.

\section{Debt Information}

\section{Statement of Direct Debt Outstanding}

This is a statement that generally starts with gross bonded debt of the issuer and is reduced by self-supporting debt and other exclusions (such as sinking funds) to arrive at the net direct debt of the issuer.

\section{Statement of Authorized But Unissued Debt}

This stateinent describes debt that has been authorized by voters or the governing body but has not yet been issued. It may represent over-estimation at the time a project was undertaken, delays in a project, or an intended project involving several issues of debt where all the financing has not been completed.

\section{Debt Service}

This statement shows the amount of principal and interest that must be paid each year starting with the current year and extending into the future on all the issuer's outstanding debt (including the proposed issue). If the proposed issue is not included, a separate debt service schedule for it should be presented.

\section{Statement of Overlapping Debt}

Local political subdivisions are usually overlapped by other bond-issuing political subdivisions. For example, a town niay be overlapped by a county, school district, special district, etc. By custom, state bonding is not included in overlapping debt for political sub-umits within the state. A statement of overlapping debt essentially shows the amount of total debt burden (exclusive of the issuer's debt) on the assessed value of property of the issuer.

\section{Debt Limit}

Some states have set constitutional or statutory debt limits. In those cases, the state legislature sets some borrowing limit, frequently by setting a percentage of full value as a niaximun for bonded debt. Local government charters or statutes may also set such limits. 


\section{Unused Borrowing Margin}

This concept applies only to local units or states with debt limits. It is usually calculated by establishing the debt limit and then subtracting the outstanding indebtedness, reduced by certain allowable exclusions, to arrive at the unused borrowing capacity.

\section{Rights of Bondholders}

This should be a narrative which informs the bond purcliaser of various legal rights, actions, agents, etc., that serve to protect his claim in the event of transfer, default, or retirement of debt.

\section{Short-term Debt}

Debt classified as short-term debt is debt issued in anticipation of other funding sources, either revenue or borrowing receipts. Tax anticipation notes are issued in the expectation of taxes to be collected. They allow an issuer to bridge a cash-flow cycle, because frequently taxes may be collected only once a year or at the end of the year, while cash demands are continuous. Bond anticipation notes provide a means of acquiring cash for specific projects with the expectation that bonds will be issued to replace the notes at a later date.

\section{Pension Plans}

Pension plans nay represent a sizeable obligation which is often partially unfunded in that insufficient assets have been set aside to match the accrued liability. In other cases, plans are centralized at the state level. In either event, the kind of pension system, the issuer's contribution, the issuer's estimated liability and other details should be disclosed in a prospectus.

\section{ECONOMIC AND DEMOGRAPHIC INFORMATION}

\section{Population}

This is either the estimated or official census population within the issuer's boundaries.

\section{Population Trends}

This information should reflect any change in population level over a period long enough to provide evidence of a trend.

\section{Individual or Median Income of Family}

The average (or median) income, either per capita or per family unit, should be disclosed for the area within the issuer's boundaries or for an appropriate overlapping area, such as the Standard Metropolitan Statistical Area (SMSA) within which the issuer lies. 


\section{Unemployment}

Information on unemployment may not be available for an issuer's area of jurisdiction on a timely basis. This information is often estimated by a state unit and reported by county or SMSA.

\section{Building Permits}

The issuer or a related political subdivision usually maintains detailed records of construction permits issued. A major increase or decrease in construction reflects the economic activity taking place within the boundaries of the issuer, which in turn affects the taxable base.

\section{Principal Firms}

A listing of the principal firms and their products provides evidence of the degree of concentration or diversification in the economic base of the issuer and its sensitivity to economic cycles.

\section{General Economic Information}

This should include a summary of major economic activities and conditions within the issuer's boundaries. This statement frequently pulls together an overview of increases or decreases in employnent, opening or closing of busmesses, expansion or contraction of governmental or service units, changes in retail sales, and banking transactions.

\section{Disclosure Information Coding Procedures}

The major problem in developing a disclosure measuring system was to classify the Guidelines' many suggested informational iteins into a quantifiable, measurable format which could be coded for coinputer use. Simce many of the items were discussed in narrative form and others might not be appropriate, careful procedures and decision rules had to be developed to insure thorough and consistent evaluation. In addition to the four substantive disclosure areas discussed above, additional data dealing with issue and issuer characteristics were collected to assist in analysis.

The first step was to develop a tentative coding sheet for each of the five sections mentioned above. To accomplish this, two researchers were assigned to each section. Each team translated the Guidelines' suggestions pertinent to a particular category into an imventory of possible items sufficiently extensive to cover all the information which might appear in the prospectuses.* As the coding format for one section was completed, it was dis-

* To translate the information content of a prospectus into a numeric measurement system, suitable for computerized analysis, numeric values were used to code the information contained im each prospectus. A ' $\alpha$ ' was used if the item was not disclosed, a ' 1 ' was assigned if the item was disclosed; a ' 9 ' was assigned if the item was judged not applicable, and the numbers ' 2 ' through ' 5 ' were used to indicate the number of prior years' information, where applicable. 
tributed to all researchers for review and criticism. Once a complete inventory was developed for each section, the entire coding form was tested on a small sample of prospectuses. This test was used to detect operational and conceptual problems in the coding process until a fimal version was developed. In all, a total of 137 items of information were coded to describe the informational content and other characteristics of each official statement.

The two researchers primarily responsible for the development of each section of the coding form were assigned to code that section of each prospectus. By this point in the project these researchers had knowledge of the information required and of the likely manner in which this information would be presented in official statements. Area specialization reduced the judgmental errors or inconsistencies that otherwise plague an often subjective process.

To insure overall quality in the coding process, a random sample of twelve prospectuses was selected for each section coded (this involved 84 different prospectuses). Each of these sections was reviewed by researchers coding different sections of the prospectuses. Problems and questions concerning interpretations, judgment, and consistency were raised and cleared.

A copy of the coding sheet and more complete tabulations of the data are available from Drs. Bourque and Forbes at the State University of New York at Albany. 